\title{
APLIKASI PATI ASETAT SEBAGAI CARRIER AGENT ANTOSIANIN DARI UBI JALAR UNGU
}

\section{APPLICATION OF ACETILATED STARCH AS ANTHOCYANIN CARRIER AGENT FROM PURPLE SWEET POTATO}

\author{
Hendy Suryandani ${ }^{1 *}$, Indah Yuliasih ${ }^{2)}$, dan Titi Candra Sunarti ${ }^{2}$ \\ ${ }^{1)}$ Program Studi Teknologi Industri Pertanian, Fakultas Teknologi Pertanian, Institut Pertanian Bogor \\ Kampus IPB Darmaga, Bogor 16680; Telp. (0251) 8621974 \\ ${ }^{2)}$ Departemen Teknologi Industri Pertanian, Fakultas Teknologi Pertanian, Institut Pertanian Bogor \\ E-mail: markovic62@yahoo.com \\ Makalah: Diterima 20 Agustus 2018; Diperbaiki 19 Maret 2019; Disetujui 10 April 2019
}

\begin{abstract}
Purple sweet potato (Ipomoea batatas L. Poir) anthocyanins is a source of natural colorant which has functional characteristic such as antioxidant, antibacterial, antimutagenic and anticarcinogen functions. The weaknesses of purple sweet potato anthocyanins are easily to degradation by $\mathrm{pH}$, temperature, and light, but it can be improved by adding carrier agent. Acetilated starch is one of modified starch that has potential to be a carrier agent because of its ability to minimize decreasing active compound. The methodologies of the research were preparation and characterization of raw material, determination of the ratio of slurry and starch acetate carrier agent (10: 1; 10: 2 and 10: 3), application of starch acetate as anthocyanin carrier agent of slurry, filtrate and purple sweet potato pulp, and powder anthocyanin stabilized test to temperature and pH. The composition raw based material contained moisture content (79.09 - 93.51\%), carbohydrates (5.63 - 20.18\%), starch (4.96 - 19.22\%), and anthocyanin content of $7.74-11.58 \mathrm{mg} / 100 \mathrm{~g}$. The ratio of slurry and starch 10:1 gave Chroma of 18.48 and ${ }^{\circ}$ Hueof 334.75. In stabilization stage, slurry form produced the best characteristics i.e. anthocyanins content of $9.87 \mathrm{mg} / 100 \mathrm{~g}$, moisture content of 2.99\%, Chroma of 15.92, ${ }^{\circ}$ Hue of 342.38, stable at a heating temperature of $80^{\circ} \mathrm{C}$ and $\mathrm{pH}$ of $3-4$ and also dissolved well at $80^{\circ} \mathrm{C}$. The result showed that acetilated starch binds purple sweet potato anthocyanins in slurry form more stable than those in filtrate and pulp.
\end{abstract}

Keywords: anthocyanins, carrier agent, acetate starch

\section{ABSTRAK}

Antosianin dari ubi jalar ungu adalah salah satu sumber pewarna alami yang memiliki sifat fungsional seperti antioksidan, antibakteri, antimutagenik, dan antikarsinogen. Namun kelemahannya adalah mudah rusak karana pengaruh suhu, $\mathrm{pH}$ dan cahaya, dan kelemahan tersebut dapat diatasi dengan menambahkan bahan carrier agent. Pati asetat merupakan pati modifikasi yang berpotensi sebagai bahan carrier agent karena kemampuannya dalam meminimalisir penurunan bahan aktif. Metodologi penelitian ini terdiri dari persiapan dan karakterisasi bahan baku, penentuan rasio slurry dan carrier agent pati asetat (10:1; 10:2; 10:3), aplikasi pati asetat sebagai carrier agent antosianin dengan bahan baku slurry, filtrat dan ampas ubi jalar ungu dan uji stabilitas antosianin powder terhadap $\mathrm{pH}$ dan Suhu. Komposisi ketiga bahan baku (slurry, filtrat dan ampas) mengandung kadar air $(79,09-93,51 \%)$, karbohidrat $(5,63-20,18 \%)$, pati $(4,96-19,22 \%)$ dan kadar antosianin $(7,74-11,58 \mathrm{mg} / 100$ g). Rasio slurry dan pati asetat 10:1 menghasilkan nilai Chroma 18,48 dan ${ }^{\circ}$ Hue 334,75. Pada tahap stabilisasi bahan baku slurry menghasilkan kadar antosianin 9,87 mg/100 g, kadar air 2,99\%, Chroma 15,92, ${ }^{\circ}$ Hue 342,38, stabil pada suhu pemanasan $80^{\circ} \mathrm{C}$ dan pada $\mathrm{pH} 3-4$ serta larut pada suhu $80^{\circ} \mathrm{C}$. Hasil penelitian menunjukkan pati asetat mengikat antosianin ubi jalar ungu dalam bentuk slurry lebih stabil dibandingkan filtrat dan ampas.

Kata kunci : antosianin, carrier agent, pati asetat

\section{PENDAHULUAN}

Antosianin dari ubi jalar ungu adalah pigmen alami yang berpotensi menjadi pengganti pewarna sintetik, selain karena spektrum warnanya yang memberikan kisaran warna dari oranye, merah, ungu hingga biru, penggunaan yang luas dari pigmen ini juga disebabkan karena manfaat kesehatan yang dimilikinya, seperti fungsinya sebagai antioksidan, antibakteri, antimutagenik, dan antikarsinogen. Menurut Zhang et al. (2009) aktivitas antioksidan ubi jalar ungu lebih tinggi dibanding jenis sayuran lain, hal ini dikarenakan kandungan antosianinnya yang tinggi.

Pada proses pengolahan pangan, kendala terbesar yang dihadapi industri dalam aplikasi pewarna antosianin ini adalah kestabilannya yang sangat rendah terutama terhadap pengaruh $\mathrm{pH}$, cahaya, dan suhu (Mazza dan Brouillard, 1990). Kestabilan antosianin dapat ditingkatkan dengan beberapa cara, diantaranya adalah dengan penambahan carrier agent. Pada proses pengeringan, carrier agent dapat berfungsi sebagai drying carrier atau wall material. Menurut Nedovic et al. (2011) 
polisakarida seperti pati dan turunannya dapat digunakan sebagai carrier agent dan salah satu contohnya adalah pati asetat yang merupakan pati modifikasi yang diperoleh dengan cara asetilasi pati alami. Pati asetat dilaporkan memiliki efisiensi yang baik sebagai carrier agent pada mikroenkapsulasi karena kemampuannya dalam membentuk film (Chowdary dan Radha, 2011).

Pewarna antosianin dalam bentuk powder biasanya diperoleh dengan cara pengeringan semprot (spray drying) pada suhu tinggi, seperti penelitian yang dilakukan oleh Ersus dan Yurdagel (2007) yang mengenkapsulasi antosianin dari wortel hitam dan Tonon et al. (2010) yang mengenkapsulasi antosianin dari acai (Euterpe oleraceae Mart). Pada penelitian ini proses pembuatan pewarna alami antosianin dalam bentuk powder dilakukan dengan menggunakan pengering oven pada suhu $50^{\circ} \mathrm{C}$, hal ini dilakukan untuk meminimalkan kerusakan antosianin karena aplikasi suhu tinggi pada proses pengeringan semprot. Tujuan dari penelitian ini adalah menghasilkan pewarna alami antosianin dari ubi jalar ungu dalam bentuk powder yang lebih stabil terhadap pengaruh suhu dan $\mathrm{pH}$ dengan penambahan carrier agent pati asetat.

\section{BAHAN DAN METODE}

\section{Bahan dan Alat}

Bahan yang digunakan pada penelitian ini terdiri dari ubi jalar ungu varietas Antin 3, carrier agent pati asetat K1Star diperoleh dari Asia Modified Starch Co.Ltd dengan standar food grade aquades, etanol, $\mathrm{HCl}, \mathrm{KCl}, \mathrm{Na}$ asetat, asam asetat, $\mathrm{NaOH}$, aquades, etanol, heksana, $\mathrm{K}_{2} \mathrm{SO}_{4}, \mathrm{HgO}, \mathrm{H}_{2} \mathrm{SO}_{4}$, $\mathrm{Na}_{2} \mathrm{~S}_{2} \mathrm{O}_{3}, \mathrm{H}_{3} \mathrm{BO}_{3}, \mathrm{CH}_{3} \mathrm{COOH}$, dan KI (Merck).

Peralatan yang digunakan pada penelitian ini terdiri dari autoclave, blender, vacuum filtration, oven, dan ayakan 100 mesh, timbangan analitik, sentrifuse, waterbath, oven, alat SEM tipe JSM5000, pH meter, spektrofotometer UV Vis Lambda 650 dan kromameter Minolta CR 310.

\section{Tahap Penelitian \\ Persiapan dan Karakterisasi Bahan Baku}

Persiapan bahan baku dilakukan dengan metode Farahmandazad (2015) yang dimodifikasi. Ubi jalar ungu dibersihkan terlebih dahulu kemudian dicuci dengan air mengalir dan dikukus (steaming) selama 15 menit. Ubi jalar ungu yang telah dikukus kemudian dimasukan ke dalam campuran pelarut air dan etanol (60:40 (v/v)) dengan perbandingan 1:2 (b/b) lalu dihaluskan dengan blender untuk mendapatkan bahan baku dalam bentuk slurry, filtrat,dan ampas. Karakteristik bahan yang akan diukur adalah kadar pati (SNI 01-2891-1992), proksimat (kadar air dan abu (AOAC 1990), protein dan lemak (SNI 01-2891-1992), dan karbohidrat by difference), $\mathrm{pH}$, warna (nilai Chroma dan ${ }^{\circ} \mathrm{Hue}$ ), dan kadar antosianin (Giusti dan Worlstad, 2001).

\section{Penentuan Rasio Slurry dan Carrier Agent Pati Asetat}

Pada tahap ini dilakukan pencampuran slurry ubi jalar ungu dengan pati asetat sebagai bahan carrier agent dengan rasio yaitu 10:1; 10:2 dan 10:3. Bentuk slurry ubi jalar ungu dipilih pada tahap ini karena dilihat dari aspek kandungan antosianin dan karakteristik bahan awalnya. Campuran kemudian dikeringkan pada suhu $50^{\circ} \mathrm{C}$ selama 23 jam. Parameter yang diamati pada pewarna antosianin dalam bentuk powder yang diperoleh adalah warna (nilai Chroma dan ${ }^{\circ} \mathrm{Hue}$ ).

\section{Aplikasi Pati Asetat Sebagai Carrier Agent Antosianin}

Aplikasi pati asetat sebagai carrier agent antosianin menggunakan metode pencampuran sederhana. Pencampuran dilakukan pada slurry, filtrat, dan ampas ubi jalar ungu yang telah dikarakterisasi pada tahap 1. Sebagai carrier agent, pati asetat yang digunakan adalah pati asetat dengan rasio terbaik pada tahap sebelumnya. Berdasarkan pendapat Aviara et al. (2010) suhu pengeringan yang digunakan adalah $50^{\circ} \mathrm{C}$. Pada setiap jam akan diukur susut bobot sebagai data untuk melihat persen penurunan bobot slurry, filtrat, dan ampas ubi jalar ungu hingga menjadi pewarna antosianin alami dalam bentuk powder. Antosianin dalam bentuk powder yang diperoleh kemudian diayak dengan ayakan 100 mesh, lalu dilakukan pengukuran rendemen, kadar air (AOAC, 1990), pH, warna (Chroma dan ${ }^{\circ} \mathrm{Hue}$ ), dan kadar antosianin (Giusti dan Worlstad, 2001).

\section{Uji Stabilitas Antosianin dalam Bentuk Powder \\ Uji stabilitas dilakukan untuk menguji} kestabilan pewarna antosianin dalam bentuk powder terpilih berdasarkan tahap sebelumnya. Uji stabilitas dilakukan terhadap $\mathrm{pH}(\mathrm{pH} 3,4,5,6,7,8$ dan 9) dan suhu (suhu ruang, 40,60 , dan $80^{\circ} \mathrm{C}$ ) sesuai metode Miksusanti et al. (2012). Selain uji stabilitas terhadap $\mathrm{pH}$ dan suhu, juga dilakukan uji kelarutan pada suhu ruang, 40, 60 dan $80^{\circ} \mathrm{C}$. Data yang diamati adalah spektrum penyerapan warna pada panjang gelombang sinar tampak 400 - $700 \mathrm{~nm}$.

Data hasil percobaan dianalisa sidik ragam dengan uji $\mathrm{F}$, apabila hasilnya berpengaruh signifikan, maka dilanjutkan uji beda nyata dengan Duncan pada tingkat kepercayaan 95\%. Pengolahan data menggunakan Microsoft Excel versi 2013.

\section{HASIL DAN PEMBAHASAN}

\section{Karakteristik Bahan baku}

Karakterisasi dilakukan untuk memperoleh informasi sifat kimia dari bahan baku slurry, filtrat, dan ampas ubi jalar ungu yang digunakan pada proses pencampuran tiga bahan baku tersebut dengan carrier agent pati asetat. Analisa dilakukan sebanyak tiga kali ulangan. Hasil karakterisasi disajikan sebagaimana yang tertera pada Tabel 1 . 
Tabel 1. Karakteristik tiga bentuk bahan baku yang berbeda

\begin{tabular}{lccc}
\hline Karakteristik Kimia & Slurry & Filtrat & Ampas \\
\hline Kadar air $(\%$ bb) & 85,13 & 93,51 & 79,09 \\
Kadar abu $(\%$ bb) & 0,19 & 0,13 & 0,28 \\
Kadar protein $(\%$ bb) & 0,69 & 0,35 & 0,34 \\
Kadar lemak $(\%$ bb) & 0,48 & 0,38 & 0,11 \\
Kadar karbohidrat by difference $(\%$ bb) & 13,51 & 5,63 & 20,18 \\
Kadar pati $(\%$ bb) & 12,56 & 4,96 & 19,22 \\
pH & 6,91 & 6,85 & 6,84 \\
Antosianin $(m g / 100$ g) & 11,58 & 10,13 & 7,74 \\
\hline
\end{tabular}

Ket : bb (bobot basah)

Berdasarkan Tabel 1 kadar air filtrat lebih tinggi dari dua bahan baku lainnya yaitu sebesar $93,51 \%$, sedangkan bahan baku dalam bentuk ampas memiliki kadar air terendah yaitu 79,09. Menurut Jimenez et al. (2011) kadar air yang tinggi dapat mempercepat degradasi antosianin, selain itu bahan dengan kadar air tinggi lebih mudah mengalami kerusakan karena pertumbuhan mikroba atau reaksi kimia tertentu seperti oksidasi.

Jumlah karbohidrat (by difference) pada tiga bahan baku bervariasi antara 5,63 - 20,18\% . Karbohidrat pada ubi jalar ungu terdiri dari pati, gula, selulosa, hemiselulosa, dan pektin. Sebagai salah satu bentuk simpanan karbohidrat, pati merupakan polimer glukosa dengan ikatan glikosidik. Kadar pati yang diperoleh pada penelitian ini berkisar antara 4,96-19,22\% lebih rendah dari kadar pati ubi jalar ungu segar menurut data DEPKES RI (1981) yaitu 22,64\%. Rendahnya kadar pati pada tiga bentuk bahan baku dapat disebabkan karena serangkaian proses yang diaplikasikan pada bahan. Salah satu proses yang dapat menurunkan kadar pati adalah pengukusan ubi jalar ungu sebelum proses pengecilan ukuran dengan alat blender. Hal ini sesuai dengan pendapat Chiwona-Karltun et al. (2015) yang menyatakan bahwa perbedaan cara proses meskipun dalam bentuk minimal dapat memberikan dampak signifikan terhadap kadar pati dari beberapa varietas ubi jalar dan kentang.

Kadar abu, protein, lemak, dan antosianin juga terdapat pada ketiga bahan baku. Kadar abu menunjukkan keberadaan mineral dan unsur organik lain dalam bahan. Jumlah kadar abu yang terdapat pada ketiga bentuk bahan baku ubi jalar ungu relatif rendah, hasil pengukuran didapat jumlah kadar abu berkisar antara 0,13-0,28\%. Secara kuantitatif kadar abu yang terdapat pada ubi jalar berasal dari mineral dalam umbi segar, pemakaian pupuk, dan kontaminasi dari tanah dan udara selama proses pengolahan. Hal ini sejalan dengan pendapat Muchtadi (1997) yang menyebutkan bahwa proporsi kadar abu dalam bahan pangan dipengaruhi oleh beberapa faktor diantaranya adalah varietas, kandungan hara tanah, iklim, daerah tempat tumbuh, kematangan tanaman, dan perlakuan tanaman.

Kadar protein yang diperoleh pada penelitian ini berkisar 0,34-0,69\% dan kadar lemak berkisar 0,11-0,48\%. Menurut Aina et al. (2009) ubi jalar seperti kebanyakan umbi lainnya memiliki kadar lemak yang rendah dan bukan merupakan sumber protein tinggi, namun keberadaan lemak dan protein pada ubi jalar ungu ini menunjukkan adanya potensi nutrisi yang dapat dimanfaatkan sebagai sumber pangan.

Kadar antosianin yang diperoleh berkisar 7,74-11,58 mg/100 g. Hasil ini lebih rendah dari antosianin varietas Antin 3 yang dihasilkan pada penelitian Jusuf et al. (2008) dengan kadar sebesar $33,89 \mathrm{mg} / 100 \mathrm{~g}$. Rendahnya kadar antosianin dapat disebabkan karena pengaruh suhu selama proses pengukusan (steaming). Menurut pendapat $\mathrm{Xu}$ et al. (2014) proses steaming secara signifikan mengurangi kandungan total antosianin sebesar 8$16 \%$.

\section{Rasio Slurry dan Carrier Agent Pati Asetat}

Pencampuran slurry dan pati asetat pada tahap ini dilakukan dengan metode pencampuran sederhana, setelah proses pengeringan pada suhu 50 ${ }^{\circ} \mathrm{C}$, dilakukan pengamatan terhadap warna antosianin dalam bentuk powder yang diperoleh yaitu nilai Chroma (C) dan ${ }^{\circ}$ Hue. Pengukuran dilakukan dengan tiga ulangan. Nilai Chroma dan ${ }^{\circ} \mathrm{Hue}$ ditunjukkan pada Tabel 2.

Berdasarkan nilai ${ }^{\circ}$ Huenya, rasio 10:1, 10:2, atau 10:3 menghasilkan antosianin dalam bentuk powder dengan warna ungu, sedangkan berdasarkan intensitasnya (nilai Chormanya), rasio 10:1 dan 10:2 memiliki intensitas yang lebih besar dibandingkan dengan rasio 10:3. Hal ini menunjukkan bahwa warna ungu rasio 10:1 dan 10:2 lebih pekat dibandingkan dengan rasio 10:3. Hasil analisa sidik ragam menunjukkan bahwa rasio slurry dan pati asetat memberikan pengaruh yang signifikan terhadap nilai Chroma, akan tetapi tidak memberikan pengaruh terhadap nilai ${ }^{\circ} \mathrm{Hue}$.

Menurut Montila et al. (2010) antosianidin dominan pada ubi jalar ungu adalah sianidin yang memberikan warna biru dan peonidin yang memberikan warna merah, substraksi warna merah dan biru menghasilkan warna ungu hingga ungu kemerahan. Visualisasi warna pada pewarna antosianin dalam bentuk powder dapat dilihat pada Gambar 1. 
Tabel 2. Nilai Chroma dan ${ }^{\circ} H u e$ antosianin powder pada rasio slurry : pati asetat yang berbeda

\begin{tabular}{ccc}
\hline Rasio & Chroma & ${ }^{o}$ Hue \\
Slurry:Pati asetat & 18,48 & 334,75 \\
$10: 1$ & 15,11 & 332,73 \\
$10: 2$ & 13,41 & 340,15 \\
\hline
\end{tabular}

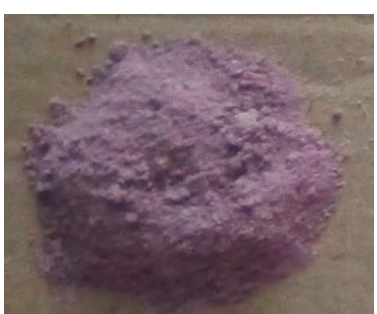

(a)

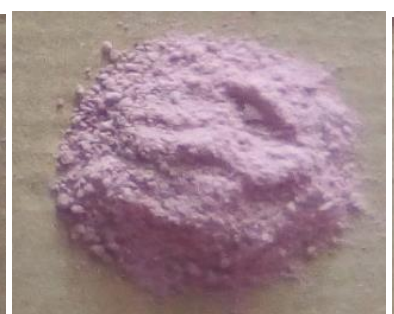

(b)

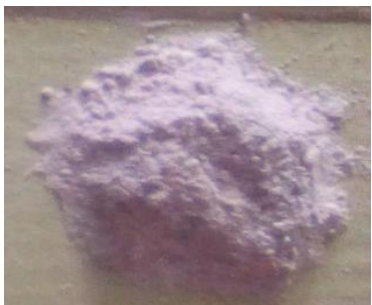

(c)

Gambar 1. Warna bubuk pewarna antosianin (a)10:1, (b) 10:2, dan (c)10:3

Antosianin merupakan pigmen warna yang dapat menunjukan visual warna yang berbeda karena perbedaan struktur, $\mathrm{pH}$, dan adanya kopigmen. Pada $\mathrm{pH}$ asalnya yaitu ketika antosianin berada dalam jaringan/vakuola tanaman antosianin berada pada bentuk kesetimbangan biru basa quinonoidal (A), merah kation flavylium $\left(\mathrm{AH}^{+}\right)$, carbinol pseudobasa (B) dan chalcone (C). Pada kondisi kesetimbangan ini, antosianin ubi jalar ungu dapat berwarna ungu atau ungu kemerahan tergantung pada rasio peonidin dan sianidin. Pada penelitian ini bahan baku dalam bentuk slurry berwarna ungu, hal ini menunjukkan bahwa jumlah sianidin lebih dominan dibandingkan dengan peonidinnya.

Setelah proses pengeringan selama 23 jam pada suhu $50^{\circ} \mathrm{C}$, pewarna antosianin dalam bentuk powder yang dihasilkan memiliki warna ungu hingga ungu kemerahan, yang menunjukkan bahwa antosianin slurry dari ubi jalar ungu lebih stabil. Hal tersebut disebabkan karena adanya antosianin dalam bentuk mono atau di-asilasi yang stabil terhadap pengaruh $\mathrm{pH}$, suhu, dan cahaya. Antosianin ubi jalar ungu mengandung bentuk mono dan diasilasi dengan asam kafeat, ferulat dan hidroksibenzoat (Tian et al., 2005). Berdasarkan hasil uji warna maka rasio slurry: pati asetat yang dipilih adalah 10:1.

\section{Karakteristik Pati Asetat sebagai Carrier Agent Antosianin}

Bahan baku ubi jalar ungu dalam bentuk slurry, filtrat ataupun ampas merupakan akumulasi dari padatan dengan sejumlah air. Air yang terdapat dalam bahan dapat berupa air bebas dan air terikat. Air bebas adalah air yang terdapat dipermukaan, diantara sel maupun dalam pori-pori, sedangkan air terikat adalah air yang terikat dengan protein, selulosa, pati, pektin atau zat lain dalam bahan (Effendi, 2009). Selama proses pengeringan, air ini akan diuapkan dari bahan sehingga menyebabkan penurunan bobot bahan. Penurunan bobot bahan atau susut bobot adalah proses kehilangan air pada bahan yang dapat disebabkan oleh transpirasi dan respirasi. Kurva persentase penurunan bobot ketiga bentuk bahan baku dari ubi jalar ungu disajikan pada Gambar 2.

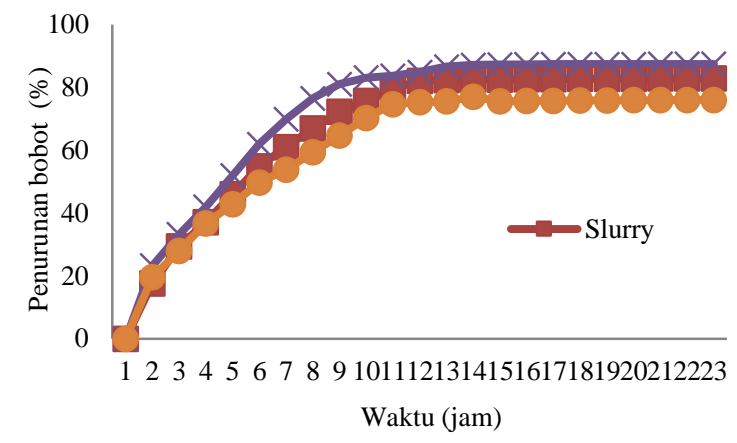

Gambar 2. Kurva penurunan bobot (\%) pada bahan baku ubi jalar ungu yang berbeda selama proses pengeringan

Berdasarkan Gambar 2, pada awal pengeringan terjadi penurunan bobot bahan yang tinggi dari ketiga bentuk bahan baku, ini ditandai dengan curamnya garis pada grafik. Penurunan bobot bahan yang tinggi ini disebabkan karena pada awal proses pengeringan, jumlah air bebas yang terdapat dipermukaan bahan masih tinggi. Menurut Ismandari (2008) air bebas adalah air yang cenderung mudah diuapkan selama periode awal pengeringan. Setelah proses pengeringan selesai untuk setiap bahan baku, selanjutnya diperoleh pewarna antosianin dalam bentuk powder dengan karakteristik seperti yang disajikan pada Tabel 3.

\section{Rendemen}

Secara umum rataan rendemen pewarna antosianin dalam bentuk powder yang dihasilkan berkisar dari 13,77 - 27,18\%. Bahan baku filtrat menghasilkan rendemen terendah (13,77\%), sedangkan bentuk ampas menghasilkan rendemen tertinggi $(27,18 \%)$. 
Tabel 3. Karakteristik antosianin powder pada bahan baku yang berbeda

\begin{tabular}{lccc}
\hline \multirow{2}{*}{ Karakteristik } & \multicolumn{3}{c}{ Bentuk bahan baku } \\
\cline { 2 - 4 } & Slurry & Filtrat & Ampas \\
\hline Rendemen (\%) & 18,83 & 13,77 & 27,18 \\
Kadar air sebelum pengeringan (\%) & 81,19 & 86,48 & 73,15 \\
Kadar air setalah pengeringan (\%) & 2,99 & 3,01 & 3,02 \\
Antosianin (mg/100g) & 9,87 & 6,29 & 3,79 \\
Chroma & 15,92 & 18,82 & 13,11 \\
${ }^{o}$ Hue & 342,38 & 352,40 & 346,53 \\
$\mathrm{pH}$ & 5,72 & 5,65 & 5,89 \\
\hline
\end{tabular}

Hasil analisa sidik ragam menunjukkan bahwa bentuk bahan baku ubi jalar ungu (filtrat, slurry dan ampas) memberikan pengaruh signifikan terhadap rendemen yang dihasilkan. Rendahnya rendemen bahan baku bentuk filtrat disebabkan karena adanya perbedaan jumlah komponen bahan seperti kadar air, karbohidrat, dan protein, dengan dua bentuk bahan baku lainnya. Selama proses pengeringan, komponen bahan terutama air akan berkurang sehingga menyebabkan rendahnya rendemen. Hal ini sesuai dengan pendapat Winarno (1993) proses pengeringan menyebabkan kandungan air bahan berkurang dan menyebabkan rendahnya rendemen yang dihasilkan.

\section{Kadar Air}

Hasil karakterisasi pada Tabel 3 menunjukkan bahwa kadar air filtrat sebelum pengeringan lebih tinggi dari slurry dan ampas, kadar air tersebut menunjukkan bahwa jumlah air bebas yang terdapat pada filtrat lebih tinggi dari dua bentuk bahan baku lainnya. Hal ini dapat dibuktikan dari bentuk kurva persentase penurunan bobot filtrat pada Gambar 2 yang lebih tinggi dan curam dari dua bahan baku lainnya.

Setelah pengeringan selesai, kadar air akhir pewarna antosianin alami dalam bentuk powder dari ubi jalar ungu berkisar 2,99 - 3,02\%. Nilai ini menunjukkan bahwa pewarna antosianin dalam bentuk powder aman dari pertumbuhan mikroorganisme karena jauh dibawah batas kadar air minimal bahan dimana mikroorganisme masih dapat tumbuh. Semakin tinggi kadar air bahan, semakin besar resiko kerusakan bahan. Kerusakan pada bahan karena faktor kadar air dapat disebabkan karena berkembangnya bakteri, kapang, dan khamir. Menurut Fardiaz (1989) batas kadar air dimana mikroba masih dapat tumbuh adalah $14-15 \%$.

\section{Kadar Antosianin}

Antosianin tergolong senyawa flavonoid yang memiliki sifat larut air, terdapat dalam bentuk aglikon sebagai antosianidin dan glikon sebagai gula yang diikat dengan ikatan glikosidik. Ubi jalar ungu mengandung antosianin dalam bentuk asilasi dengan beberapa jenis asam fenolik. Adanya antosianin dalam bentuk asilasi ini menyebabkan sifat kelarutan antosianin pada ubi jalar ungu berubah. Menurut penelitian Winarti et al. (2008) menyebutkan bahwa antosianin ubi jalar ungu memiliki sifat kurang polar dibandingkan dengan air karena dapat terekstrak pada kisaran polaritas 32,77 dibandingkan dengan polaritas air yang berkisar pada nilai 80,40. Kadar antosianin bahan sebelum dan setelah pengeringan disajikan pada Gambar 3 .

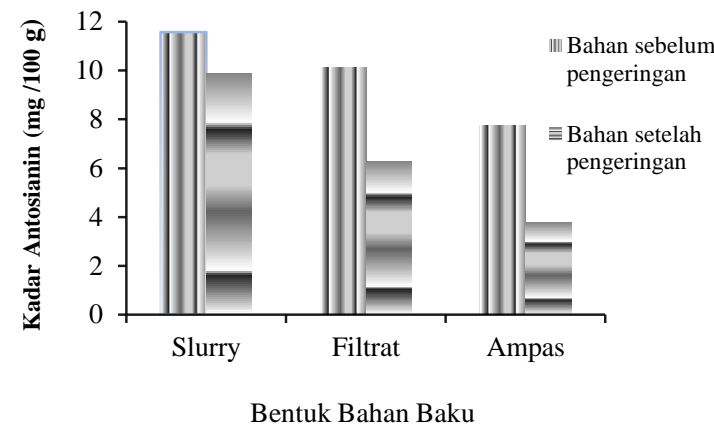

Gambar 3. Kadar atosianin bahan sebelum dan setelah pengeringan

Berdasarkan hasil yang diperoleh, secara umum terdapat penurunan kadar antosianin setelah proses pengeringan. Persen penurunan kadar antosianin terkecil terdapat dalam bentuk slurry yaitu sebesar $14,64 \%$, jika dibanding dua bentuk lainnya yaitu filtrat sebesar $38,15 \%$ dan ampas sebesar 50,68\%. Antosianin adalah senyawa flavonoid yang kestabilannya dipengaruhi oleh beberapa faktor diantaranya yaitu struktur kimia, konsentrasi, pH, suhu, cahaya, adanya kopigmen, enzim, oksigen, asam askorbat, gula, dan sulfur dioksida (Cavalcanti et al., 2011). Terdapat dua mekanisme degradasi antosianin karena pengaruh suhu, mekanisme yang pertama adalah hidrolisis ikatan glikosidik yang menyebabkan terbentuknya aglikon yang labil dan mekanisme yang kedua adalah terbukanya cincin flavylium yang merubah bentuk antosianin menjadi struktur chalcone (Simpson, 1985).

Degradasi antosianin juga dapat disebabkan oleh adanya aktifitas enzim $\alpha$-amilase yang menghidrolisis pati menjadi gula sederhana seperti maltosa, dekstrin, dan glukosa selama proses pengukusan. Menurut Kita et al. (2013) degradasi antosianin dapat terjadi selama proses pemasakan karena adanya gula reduksi yang memicu terjadinya 
reaski mailard. Penambahan pati asetat sebagai carrier agent pada slurry, filtrat, dan ampas ubi jalar ungu diharapkan dapat mengurangi kerusakan antosianin, akan tetapi pada penelitian ini hanya bahan baku berbentuk slurry saja yang memiliki persen penurunan antosianin yang rendah $(14,64 \%)$. Persentase penurunan yang rendah diduga disebabkan oleh mekanisme pengikatan gugus asetil pati asetat dengan gugus asil pada antosianin. Pati asetat memiliki gugus asetil yang bersifat nonpolar yang dapat berikatan dengan antosianin asilasi yang memiliki sifat semipolar, sedangkan gugus hidroksil yang tidak tersubstitusi akan berikatan dengan molekul air, protein atau antosianin non asilasi yang polar.

\section{Warna}

Karakateristik selanjutnya adalah warna, pada penelitian ini warna yang diukur adalah nilai Chroma dan ${ }^{\circ}$ Hue. Secara visual warna antosianin dalam bentuk powder yang dihasilkan adalah ungu hingga ungu kemerahan. Untuk melihat secara detil warnanya maka dilakukan pengukuran dengan menggunakan alat kromameter dan disajikan pada Tabel 4.

Pewarna alami antosianin dalam bentuk powder dari masing-masing bentuk bahan baku secara umum didominasi oleh warna merah yang merupakan warna dari peonidin dan biru yang berasal dari sianidin. Menurut Castaneda-Ovando et al. (2009) pada pH 4-6 antosianin berada dalam bentuk kesetimbangan yang memberikan warna ungu (violet). Hal ini sesuai dengan hasil pengukuran $\mathrm{pH}$ ketiga bentuk bahan baku yang berkisar antara 5,65 - 5,89 dan warna ini juga sesuai dengan nilai ${ }^{\circ}$ Hue yang diperoleh yaitu $342,38-$ 352,40 , nilai ini terdapat pada kuadran IV dalam diagram warna yang memiliki kisaran warna dari biru hingga ungu. Sedangkan nilai Chroma pewarna antosianin dalam bentuk powder untuk bahan baku slurry, filtrat, dan ampas secara berurutan adalah $15,92,18,82$, dan 13,11 . Hasil perhitungan uji sidik ragam menunjukkan hasil yang tidak signifikan untuk semua perlakuan. Semakin tinggi nilai Chroma semakin tinggi intensitas warna yang dihasilkan.

Pada penelitian ini pati asetat belum berfungsi secara efektif sebagai carrier agent, akan tetapi penambahan pati asetat pada penelitian ini terbukti dapat mengurangi persentase penurunan kadar antosianin pada slurry, filtrat, dan ampas. Berdasarkan persentase penurunan kadar antosianin, bentuk bahan baku yang dipilih untuk uji stabilitas adalah slurry yang memiliki persentase penurunan lebih rendah dari dua bentuk bahan baku lainnya yaitu $14,64 \%$, memiliki warna visual ungu dengan nilai ${ }^{\circ}$ Hue 342,38, dan Chroma 15,92.

\section{Pengaruh pH terhadap Stabilitas Antosianin Ubi Jalar Ungu dalam Bentuk Powder}

Secara alami antosianin akan menunjukkan warna yang berbeda tergantung pada struktur molekulnya. Selain struktur molekulnya, warna antosianin juga dipengaruhi oleh $\mathrm{pH}$ lingkungan. Warna antosianin pada $\mathrm{pH}$ yang berbeda ditampilkan pada Gambar 4. Pada pH 3 - 4 antosianin alami berwarna merah, $\mathrm{pH} 5$ - 6 berwarna ungu, $\mathrm{pH} 7$ berwarna ungu kebiruan, $\mathrm{pH} 8$ berwarna biru dan $\mathrm{pH}$ 9 berwarna hijau kekuningan.

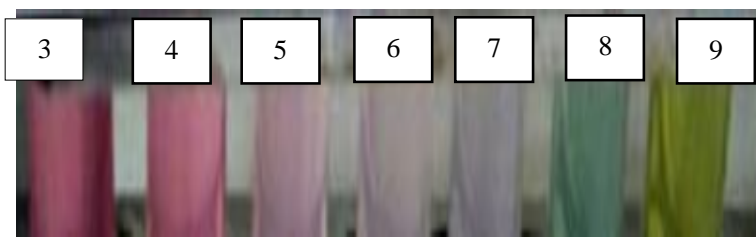

Gambar 4. Kisaran warna antosianin pada pH 3 - 9

Perubahan warna yang terjadi dari merah menjadi ungu, biru hingga berwarna kuning kehijauan menunjukkan bahwa $\mathrm{pH}$ dapat mempengaruhi kestabilan antosianian. Antosianin umumnya lebih stabil pada kondisi asam dibandingkan pada kondisi netral-basa. Pada $\mathrm{pH}$ di bawah 5 warna antosianin ubi jalar ungu tetap berwarna merah, dan mulai berubah menjadi ungu, biru hingga kuning kehijauan pada $\mathrm{pH}>5$. Menurut Brouillard (1982) pada $\mathrm{pH}$ rendah (1-2) antosianin berada pada bentuk kation flavilium yang merupakan bentuk paling stabil. Perubahan warna oleh pH terjadi karena perubahan struktur antosianin dari kation flavylium menjadi pseudobasa carbinol, quinonoidal dan chalcone (Cisneros-Zevalos dan Cevallos-Casals, 2004).

Tabel 4. Perubahan nilai Chroma dan ${ }^{\circ}$ Hue pada bahan baku yang berbeda

\begin{tabular}{lcc}
\hline \multicolumn{1}{c}{ Sampel pada tahapan proses } & Rataan Chroma & Rataan ${ }^{\text {Hue }}$ \\
\hline Slurry (S) & 10,52 & 42,61 \\
Slurry + pati asetat (S') & 14,15 & 50,26 \\
Slurry setelah pengeringan (S',) & 15,92 & 342,38 \\
Filtrat (F) & 11,99 & 46,46 \\
Filtrat + pati asetat (F') & 14,54 & 47,49 \\
Filtrat setelah pengeringan (F',) & 18,82 & 352,40 \\
Ampas (A) & 16,03 & 43,12 \\
Ampas + pati asetat (A') & 18,56 & 52,51 \\
Ampas setelah pengeringan (A') & 13,11 & 346,53 \\
\hline
\end{tabular}


Perubahan warna karena pengaruh $\mathrm{pH}$ juga dapat diamati dari serapan warna dengan mengukur absorbansinya pada panjang gelombang sinar tampak menggunakan spektrofotometer UV-Vis. Spektrum serapan warna dari pewarna antosianin dalam bentuk powder mengalami pergeseran (shifting) seiring dengan perubahan $\mathrm{pH}$. Pada $\mathrm{pH} 3$ 4 antosianin memiliki penyerapan sinar maksimum pada panjang gelombang $520 \mathrm{~nm}$. Setelah $\mathrm{pH}$ ditingkatkan menjadi $\mathrm{pH} 5$ - 6 terjadi pergeseran gelombang ke arah panjang gelombang yang lebih tinggi atau batokromik (bathocromic shift) dari panjang gelombang $520 \mathrm{~nm}(\mathrm{pH} 4)$ menuju $540(\mathrm{pH}$ 5 - 6). Grafik pola spektra absorbansi $\mathrm{pH}$ 3-9 dapat dilihat pada Gambar 5.

Pada pH 7 antosianin memiliki penyerapan sinar maksimum pada panjang gelombang $560 \mathrm{~nm}$. Pada $\mathrm{pH} 8$ - 9 panjang gelombangnya bergeser menjadi $600 \mathrm{~nm}$ yang diikuti dengan perubahan warna menjadi biru ( $\mathrm{pH}$ 8) dan hijau kekuningan ( $\mathrm{pH}$ 9). Pergesaran panjang gelombang ini menunjukkan terjadinya perubahan warna merah menjadi ungu dan ungu kebiruanpada $\mathrm{pH} 4$ - 7, kemudian dari biru menjadi hijau kekuningan pada pH $8-9$.

\section{Pengaruh Suhu terhadap Stabilitas Antosianin Ubi Jalar Ungu dalam Bentuk Powder}

Uji stabilitas terhadap suhu dilakukan dengan memanaskan larutan pewarna antosianin dalam bentuk powder pada suhu 40, 60 dan $80^{\circ} \mathrm{C}$ selama 30 menit kemudian diukur spektrum penyerapan warnanya pada panjang gelombang sinar tampak (Miksusanti et al., 2012). Spektrum penyerapan warna diukur pada panjang gelombang sinar tampak (400 - $700 \mathrm{~nm})$ dan hasilnya ditunjukkan pada Gambar 6.

Hasil yang diperoleh pada Gambar 6 menunjukkan bahwa pada suhu 40, 60 atau $80{ }^{\circ} \mathrm{C}$ pewarna antosianin memiliki spektrum penyerapan absorbansi maksimum pada panjang gelombang 520 $\mathrm{nm}$. Masing-masing antosianin memiliki absorbansi maksimal pada panjang gelombang tertentu. Menurut Henry (1996) sianidin memiliki absorbansi maksimal pada panjang gelombang 514 - $523 \mathrm{~nm}$. Hasil ini juga menunjukkan bahwa antosianin masih dapat terukur meskipun dipanaskan hingga suhu $80^{\circ} \mathrm{C}$. Hal ini disebabkan karena pewarna antosianin dalam bentuk powder dari slurry ubi jalar ungu mengandung antosianin terasilasi yang stabil terhadap suhu (Montila et al., 2011).

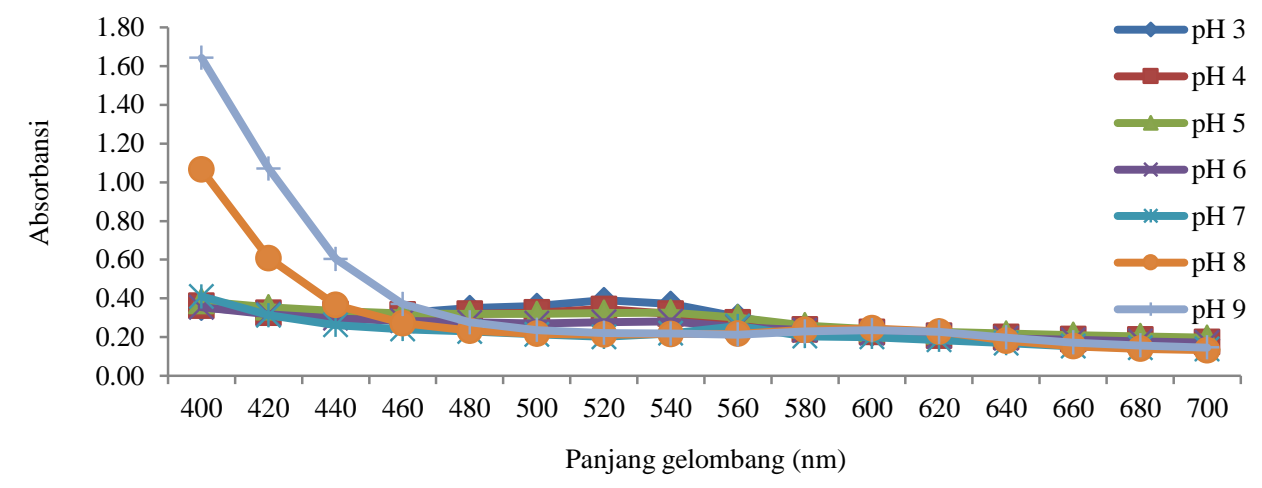

Gambar 5. Pola spektra absorbansi warna antosianin pada $\mathrm{pH}$ 3-9

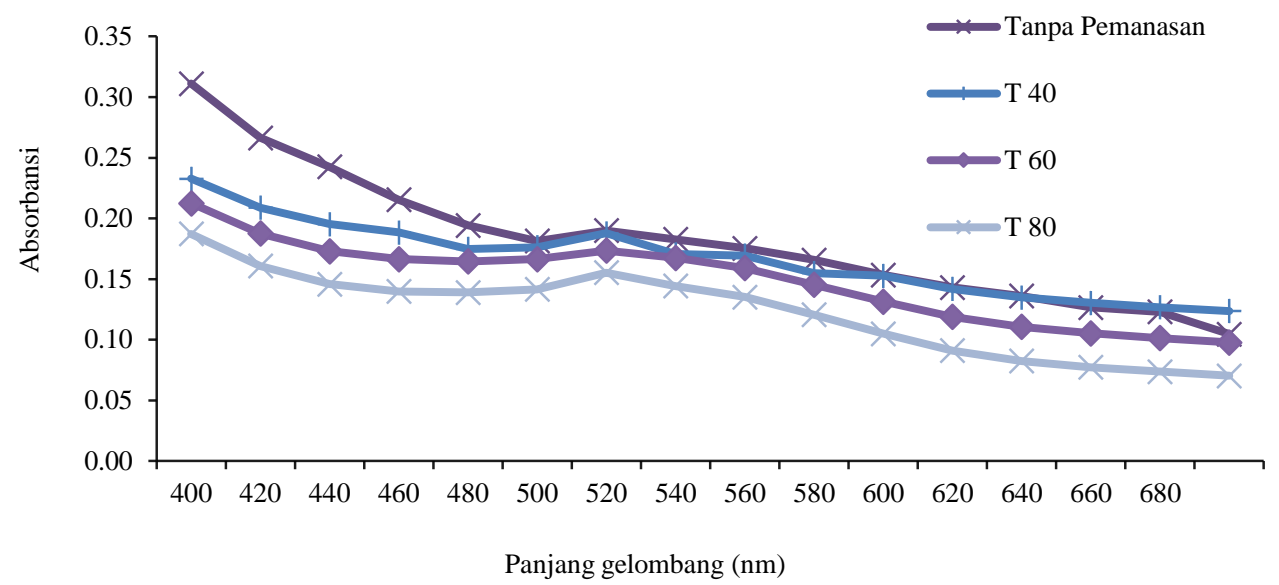

Gambar 6. Pola spektra absorbansi warna antosianin pada berbagai suhu 
Pada penelitian lain penurunan antosianin sebesar $48 \%$ terjadi setelah penyimpanan selama 7 hari pada suhu $80^{\circ} \mathrm{C}$ (Amr dan Tamimi, 2007). Kestabilan pewarna antosianin tersebut, diduga juga dapat disebabkan karena adanya pati asetat yang stabil terhadap panas dan berfungsi sebagai pengikat gugus asil antosianin sehingga dapat meminimalkan proses hidrolisis ikatan glikosidik.

\section{Kelarutan}

Uji kelarutan sediaan bubuk pewarna dilakukan pada pelarut air pada suhu ruang, 40, 60 dan $80^{\circ} \mathrm{C}$. Pengujian dilakukan sebanyak tiga kali ulangan dan hasil uji kelarutan pewarna antosianin disajikan pada Tabel 5.

Tabel 5. Kelarutan pewarna antosianin pada suhu berbeda

\begin{tabular}{cc}
\hline Suhu $\left({ }^{\circ} \mathbf{C}\right)$ & Kelarutan $(\%)$ \\
\hline Ruang & 35,16 \\
40 & 49,64 \\
60 & 54,97 \\
80 & 72,36 \\
\hline
\end{tabular}

Hasil pengujian menunjukkan bahwa semakin tinggi suhu pemanasan menyebabkan kelarutan semakin tinggi. Kelarutan terbesar terdapat pada pewarna antosianin dalam bentuk powder yang dilarutkan dengan suhu $80^{\circ} \mathrm{C}$. Kelarutan dalam air menunjukkan adanya padatan terlarut dalam sampel, pada suhu yang lebih tinggi terjadi pemecahan powder dan sebagian besar senyawa dengan bobot molekul rendah keluar dan larut pada air (Spada et al., 2012). Suhu yang tinggi akan mengganggu ikatan intermolekuler pada pati dan menyebabkan terbentuknya ikatan hidrogen antara pati dengan air. Selain itu, kelarutan yang tinggi pada suhu $80{ }^{\circ} \mathrm{C}$ disebabkan karena sifat asal dari pati asetat yang memiliki kelarutan yang rendah pada suhu ruang. Adanya gugus asil pada pada pati menyebabkan pati menjadi lebih stabil, akan tetapi karena suhu $80{ }^{\circ} \mathrm{C}$ lebih tinggi dari suhu gelatinisasi pati $\left(65^{\circ} \mathrm{C}\right)$ maka akan menyebabkan terjadinya penuruan ukuran dan jumlah bagian kristalin dan menyebabkan pati menjadi lebih amorpous yang tidak tahan panas sehingga kelarutannya menjadi tinggi (Re, 1998).

\section{KESIMPULAN DAN SARAN}

\section{Kesimpulan}

Pewarna antosianin alami dalam bentuk powder dapat diperoleh dengan proses pencampuran dengan menambahkan pati asetat sebagai carrier agent dan dikeringkan dengan pengering oven pada suhu $50^{\circ} \mathrm{C}$. Rasio bahan baku (slurry, filtrat dan ampas) ubi jalar ungu dengan pati asetat terbaik adalah 10:1. Pengaruh tiga bentuk bahan baku terhadap antosianin ubi jalar ungu dalam bentuk powder yang dihasilkan menunjukkan adanya penurunan kadar antosianin sebelum dan setelah pengeringan, pergeseran warna (nilai Chroma dan ${ }^{\circ} \mathrm{Hue}$ ), adanya perubahan spektrum penyerapan warna pada panjang gelombang sinar tampak seiring peningkatan $\mathrm{pH}$, dan memiliki absorbansi maksimum sebesar $520 \mathrm{~nm}$ setelah pemanasan pada suhu 40,60 atau $80^{\circ} \mathrm{C}$. Hasil penelitian menunjukkan pati asetat mengikat antosianin ubi jalar ungu dalam bentuk slurry lebih stabil dibandingkan filtrat dan ampas

\section{Saran}

Pati asetat pada penelitian ini berfungsi sebagai bahan pengikat gugus asil antosianin dari ubi jalar ungu sehingga dapat dipertimbangkan untuk digunakan sebagai carrier agent. Proses pemekatan atau penguapan vakum dapat ditambahkan pada proses persiapan ekstraksi antosinian dari ubi jalar ungu untuk mendapatkan kadar antosianin yang lebih tinggi. Perlu penambahan emulsifier pada proses pencampuran slurry/filtrate/ampas dengan carrier agent pati asetat sehingga kelarutan menjadi lebih baik.

\section{DAFTAR PUSTAKA}

Aina AJ, Falade KO, Akingbala JO, Titus P. 2009. Physicochemical properties of twenty-one caribbean sweet potato cultivars. J Int Food SciTech. 44: 1696-1704.

Amr A, Al-Tamimi E. 2007. Stability of the crude extracts of Ranunculus asiaticusanthocyanins and their use as food colourants. J Int Food Sci Tech.42(8):985991

[AOAC] Association of Official Analytical Chemists. 1990. Official Methods of Analysis of The Association of Official Analytical Chemists. Washington DC. (US): AOAC inc.

Aviara NA, Igbeka JC, dan Nwokocha LM. 2010. Physicochemical properties of sorghum (Sorghum bicolor L. Moench) starch as affected by drying temperature.12(2):85-98.

Brouillard R. 1982. Chemical Structure of Anthocyanins in $P$. Markakis (Ed). Anthocyanins AsFood Colour. p: 26-28. New York (NY): Academic Press.

Cavalcanti RN, Santos DT, dan Meireles MAA. 2011. Non thermal stabilization mechanisms of anthocyanins in model and food systems an overview. J Food ResInt. 44(2): 499-509.

Chiwona-Karltun L, Afoakwa EO, Nyirenda D, Mwansa CN, Kongor EJ, Brimer L. 2015. Varietal diversity and processing effects on the biochemical composition, cyanogenic glucoside potential ( $\mathrm{HCNp}$ ) and appearance of cassava flours from south-eastern african 
region. Journal International Food Resch. 22(3): 973-980.

Chowdary KPR dan Radha GV. 2011. Syinthesis, characterization and evaluation of starch acetate as microencapsulating agent for controlled release of nifedipine. Journal International Chemical Science. 9(2): 57358.

Cisneros-Zevallos L dan Cevallos-Casals. 2004. Stability of anthocyanin based aqueous extracts of andean purple corn and red fleshed sweet potato compared to synthetic and natural colorants. Journal Food Chemisty. 86: 69-77.

[DEPKES RI] Departemen Kesehatan RI. 1981. Daftar Komposisi Bahan Makanan. Jakarta (IDN): Bhatara Karya Aksara.

Effendi S. 2009. Teknologi Pengolahan dan Pengawetan Pangan. Bandung (IDN): Alfabeta.

Ersus S dan Yurdagel U. 2007. Microcapsulation of anthocyanin pigments of black carrot (Daucuscarota L.) by spray drier. Journal Food Eng. 80:805 - 812.

Farahmandazad H. 2015. Recovery and Purification of Anthocyanins from Purple-Blue Potato (thesis). Helsinki. LUT School of Engineering Science.

Fardiaz S. 1989. Mikrobiologi Pangan. Pusat Antar Universitas Pangan dan Gizi. Bogor (IDN): Institut Pertanian Bogor.

Giusti MM dan Worlstad RE. 2001. Charecterirization and Measurement of Anthocyanin by UV Visible Spectroccopy.United State of America (USA): Oregon State University.

Henry BS. 1996. Natural Food Colours. In Heap, HendryGAF, Houghtom JD. (Eds). Natural Food Colorants.2 ${ }^{\text {nd }}$ ed : 40-79. United Kingdom (UK): Blackie Academic and Professional.

Ismandari T, Hakim L, Hidayat C, Supriyanto, Pratono Y. 2008. Pengeringan Kacang Tanah Menggunakan Solar Dryer. Fakultas Teknologi Pertanian. Universitas Gajah Mada. Yogyakarta (IDN): UGM press.

Jimenez-Aguilar DM, Gaithersburg Maryland, Ortega-Regules AE, JD Lozada-Ramírez MI, Perez-Perez EJ, Vernon-Carter, WeltiChanes J. 2011. Color and chemical stability of spray dried blueberry extract using mesquite gum as wall material. Journal Food Comp Analys. 24(6): 889894.

Jusuf StM, Rahayuningsih A, dan Ginting E. 2008. Ubi jalar ungu. Warta Penelitian dan Pengembangan Pertanian. 30(4).

Kita A, Bąkowska-Barczak A, Hamouz K, Kułakowska K, Grażyna Lisińska G. 2013. The effect of frying on anthocyanin stability and antioxidant activity of crisps from red and purple fleshed potatoes (Solanum tuberosum L.). Journal Food Comp Analys.32:169-175.

Mazza G dan Brouillard R.1990. The mechanism of co-pigmentation of anthocyanins in aqueous solutions. Phytochem. 29:1097 1102.

Miksusanti, Elfita, dan Hotdelina S. 2012. Aktivitas antioksidan dan sifat kestabilan warna campuran ekstrak etil asetat kulit buah manggis (Garcinia mangostana L.) dan kayu secang (Caesalpinia sappan L.). Jurnal Penelitian Sains. 12(2):60-69.

Montilla EC, Hillebrand S, Butschbach D, Baldermann S, Watanabe N, Winterhalter P. 2010. Preparative Isolation of Anthocyanins from Japanese Purple Sweet Potato (Ipomoea batatas L.) Varieties by High Speed Countercurrent Chromatography. Journal Agricultur Food Chemistry. 58:9899-9904.

Montila EC, Hillebrand S, dan Winterhalter P. 2011. Anthocyanin in purple sweet potato (Ipomoea batatas L) varieties. FVC $S$ Science Biotech. 5: 19-24.

Muchtadi TR. 1997. Teknologi Proses Pengolahan Pangan. Departemen Pendidikan dan Kebudayaan Direktorat Jenderal Pendidikan Tinggi Pusat Antar Universitas Pangan dan Gizi.Bogor (IDN).Institut Pertanian Bogor.

Nedovic V, Ana K, Verica M, Steva L, Branko B. 2011. An overview of encapsulation technologies for foodapplications. Journal Proc Food Science. 1: 1806 - 1815.

[SNI] Standar Nasional Indonesia. 1992. Cara Uji Protein, Pati dan Lemak (SNI 01-28911992). Jakarta(ID): Badan Standardisasi Nasional.

Re MI. 1998. Microencapsulation by spray drying. Drying Tech.16: 1195 - 1236.

Simpson KL. 1985. Chemical Changes In Natural Food PigmentsinChemical Changes In Food During Processing pp. 409-441. NewYork (NY). Van Nostrand Reinhold.

Spada JC, Marczak LDF, Tessaro IC, Zapata Norena CPZ. 2012. Microencapsulation of beta carotene using native pinhao starch, modified pinhao starch and gelatin by freeze drying. International Food Science Techonoly. 47: 186 - 194.

Tian Q, Konczak I, dan Schwartz SJ. 2005. Probing anthocyanin profiles in purple sweet potato cell line (Ipomoea batatas L. Cv. Ayamurasaki) by high performance liquid chromatography and electrospray ionization tandem mass spectrometry. Journal Agr Food Chem. 53: 6503-6509.

Tonon RV, Brabet C, dan Hubinger D. 2010. Anthocyanin stability and antioxidant 
activity of spray dried acai (Euterpe oleracea Mart.) juice produced with different carrier agents. Food Res Int. 43:907-914.

Winarno FG. 1993. Enzim Pangan. Jakarta (IDN). PT Gramedia Pustaka Utama.

Winarti S, Sarofi U, dan Anggrahini D. 2008. Ekstraksi dan stabilitas warna ubi Jalar ungu (Ipomoea batatas L.) sebagai pewarna alami. Jurnal Teknik Kimia. 3:207-214.

Xu J, Su X, Lim S, Griffin J, Carey E, Katz B, Tomich J, Scott JS, WangW. 2014. Characterisation and stability of anthocyanins in purple fleshed sweet potato P40. Journal Food Chemisty.186 (1): 9096.

Zhang ZF, Fan SH, Zheng YL, Lu J, Wu D M, Shan Q, Hu B. 2009. Purple sweet potato color attenuates oxidative stress and inflammatory response induced by dgalactose in mouse liver. Food ChemToxic.47(2) : 496-501. 